\title{
TINJAUAN HUKUM DAN AKIBATNYA TERHADAP WASIAT TANPA AKTA NOTARIS DITINJAU DARI KOMPILASI HUKUM ISLAM DAN KITAB UNDANG-UNDANG HUKUM PERDATA
}

\author{
Adam Lukmanto \\ Munsharif Abdul Chalim
}

\begin{abstract}
ABSTRAK
Penelitian ini menggunakan pendekatan yuridis normatif, pengumpulan datanya ditekankan pada sumber bahan hukum primer, berupa peraturan perundang-undangan dengan penelaahan kaidah hukum dan teori ilmu hukum. Wasiat tanpa akta Notaris dalam pandangan KHI tidak ada kewajiban mengikut sertakan Notaris dalam pembuatan wasiat sedangkan KUH Perdata diwajibkan mengikut sertakan Notaris. Persamaan wasiat tanpa akta Notaris dalam KHI dengan KUH Perdata adalah mempunyai dasar hukum tertulis, merupakan pernyataan terakhir dari pewasiat setelah sebelum meninggal dunia dan pelaksanaannya setelah si pemberi wasiat meninggal dunia, dapat dicabut dan dapat gugur atau dibatalkan, mempunyai tujuan untuk kemaslahatan manusia agar tidak terjadi pertengkatan di antara ahli waris.

Perbedaan wasiat tanpa akta Notaris dalam KHI minimal umur 21 tahun sedangkan KUH Perdata minimal umur 18 tahun, dilihat dari yang menerima wasiat dalam KHI yaitu orang lain atau lembaga sedangkan KUH Perdata orang luar dan ahli waris, dilihat dari bentuknya dalam KHI yaitu lisan atau tertulis atau dihadapan Notaris sedangkan KUH Perdata tertulis di hadapan Notaris atau dititipkan/disimpan oleh Notaris, dilihat dari batasan pemberian wasiat dalam KHI yaitu maksimal 1/3 dari seluruh harta warisan sedangkan KUH Perdata maksimal 1/2 harta jika pewasiat mempunyai seorang anak, 1/3 jika memiliki dua orang anak, dan 1/4 jika memiliki tiga orang anak, kesemuanya itu merupakan anak yang sah termasuk dalam pengertian anak turun sebagai pengganti anak dalam garis turun masingmasing dan maksimal 1/2 apabila pewasiat hanya meninggalkan ahli waris garis lurus ke atas, anak luar kawin yang telah diakui secara sah. Akibat hukum wasiat tanpa adanya akta Notaris, menjadikan wasiat tersebut rawan akan gugatan dari pihak-pihak yang berkepentingan karena pembuktiannya kurang kuat dan tidak ada kepastian hukum.
\end{abstract}

Kata kunci : Wasiat, KHI dan KUH Perdata, Akta Notaris.

\section{A. Latar Belakang Masalah}

Wasiat adalah pesan terakhir yang disampaikan oleh orang yang akan meninggal (biasanya berkenaan dengan harta kekayaan dan sebagainya) ${ }^{1}$. Di dalam Kompilasi Hukum Islam (KHI), wasiat adalah pemberian suatu benda dari pewaris kepada orang lain atau lembaga yang akan berlaku setelah pewaris meninggal dunia. ${ }^{2}$ Pasal $875 \mathrm{KUH}$ Perdata berbunyi surat wasiat (testamen acte) adalah sebuah akta berisi pernyataan seseorang tentang apa yang dikehendakinya terjadi setelah ia meninggal, yang dapat dicabut kembali olehnya. ${ }^{3}$ Akta Notaris adalah akta otentik yang dibuat oleh atau di hadapan Notaris menurut bentuk dan tata cara yang ditetapkan dalam undangundang. Akta otentik sendiri memiliki kekuatan pembuktian yaitu kekuatan pembuktian formil yang membuktikan antara para pihak bahwa mereka sudah menerangkan apa yang ditulis dalam akta tersebut.

\footnotetext{
${ }^{1}$ http://kbbi.web.id/wasiat. Diakses Tanggal 28 November 2016

${ }^{2} 2015$, Undang-Undang R.I Nomor 1 Tahun 1974 Tentang Perkawinan \& Kompilasi Hukum Islam. Citra Umbaran, Bandung, h. 375

${ }^{3} 2010$, Kitab Undang-Undang Hukum Perdata (Burgerlijk Wetboek), Citra umbara, Bandung, h. 236.
}

Kekuatan pembuktian mengikat yang membuktikan bahwa antara para pihak dan pihak ketiga bahwa pada tanggal tersebut dalam akta yang bersangkutan telah menghadap kepada pegawai umum dan menerangkan apa yang ditulis tersebut. ${ }^{4}$

Dalam menjalankan jabatannya, seorang Notaris berkewajiban untuk membuat daftar akta yang berkenaan dengan wasiat menurut urutan waktu pembuatan akta setiap bulan, mengirimkan daftar akta wasiat atau daftar nihil yang berkenaan dengan wasiat ke Pusat Daftar Wasiat pada Kementerian urusan pemerintahan di bidang hukum dalam waktu 5 (lima) hari pada minggu pertama setiap bulan berikutnya, serta mencatat repertorium tanggal pengiriman daftar wasiat pada setiap akhir bulan. ${ }^{5}$ Sebagian besar masyarakat Indonesia masih kurang begitu sadar

\footnotetext{
${ }^{4}$ Sutantio, Retnowulan dan Iskandar Oeripkartawinata, 1979, Hukum Acara Perdata Dalam Teori dan Praktek, Mandar Maju, Bandung, h. 67.

${ }^{5}$ Habib Adjie, 2015, Penafsiran Tematik Hukum Notaris Indonesia Berdasarkan UndangUndang Nomor 2 Tahun 2014 Tentang Perubahan Atas Undang-Undang Nomor 30 Tahun 2004 Tentang Jabatan Notaris, Refika Aditama, Bandung, h. 257 .
} 
dengan pembuatan wasiat menggunakan akta Notaris padahal dengan uraian di atas dapat diketahui bahwa wasiat dengan menggunakan akta wasiat sangatlah penting.

Kedudukan akta wasiat perlu diketahui dalam aturan hukum berdasarkan KHI dan KUH Perdata, dalam rangka untuk menjamin kepastian hukum. Berdasarkan uraian dari latar belakang masalah di atas, penulis tertarik untuk melakukan penelitian dengan judul "Tinjauan Hukum Dan Akibatnya Terhadap Wasiat Tanpa Akta Notaris Ditinjau Dari Kompilasi Hukum Islam Dan Kitab Undang-Undang Hukum Perdata".

\section{B. Rumusan Masalah}

Berdasarkan latar belakang masalah tersebut, maka penulis merumuskan masalah dalam penelitian ini sebagai berikut :

1. Bagaimana wasiat tanpa akta notaris dalam pandangan KHI dan KUH Perdata?

2. Apa persamaan dan perbedaan wasiat tanpa akta Notaris dalam KHI dengan KUH Perdata?

3. Bagaimana akibat hukum wasiat tanpa adanya akta Notaris?

\section{Pembahasan}

\section{Wasiat Tanpa Akta Notaris Dalam Pandangan KHI dan KUH Perdata.}

Pasal 195 ayat (1) KHI menyebutkan, wasiat dilakukan secara lisan di hadapan dua orang saksi, atau tertulis di hadapan dua orang saksi, atau di hadapan Notaris. Sedangkan wasiat secara formil, dari beberapa ketentuan KUH Perdata yang disebutkan di atas, surat wasiat harus dibuat tertulis di hadapan Notaris atau dititipkan/disimpan oleh Notaris. Yahya Harahap juga menyatakan bahwa timbul antara wasiat tersebut terletak pada tertulis dan tidak tertulisnya surat wasiat dihadapan Notaris. Artinya bahwa Notaris menurut KUH Perdata dituangkan dalam bentuk akta dan akta Notaris, sedangkan menurut KHI dapat berbentuk lisan atau tertulis. ${ }^{6}$

\section{Persaman dan Perbedaan Wasiat Tanpa Akta Notaris Dalam KHI dan KUH Perdata.}

a. Persamaan Wasiat Dalam KHI dan KUH Perdata.

Dalam KHI dan KUH Perdata sama-sama mempunyai dasar hukum tertulis. Pada dasarnya dalam kedua sistem hukum tersebut yakni KHI dan KHU Perdata, wasiat merupakan pemberian yang digantungkan pada kejadian meninggal dunianya orang yang berwasiat, baik pemberian tersebut dengan atau tanpa persetujuan dari yang akan diberi atau yang akan menerima wasiat. Dalam KHI dan

\footnotetext{
${ }^{6}$ Yahya Harahap,1993, Kedudukan, Kewenangan dan Acara Peradilan Agama, Pustaka Kartini, Jakarta, h. 167.
}

KUH Perdata wasiat sama-sama dapat dicabut dan dapat gugur atau dibatalkan. Adapun pencabutan wasiat menurut KHI antara lain diatur dalam Pasal 199. Menurut Maman Suparman ${ }^{7}$, pencabutan wasiat menurut dalam KUH Perdata ada tiga cara yaitu pencabutan secara tegas, pencabutan dengan diam-diam dan pencabutan karena pengasingan. Dalam KUH Perdata menurut Maman Suparman, ${ }^{8}$ gugurnya wasiat diatur dalam Pasal 999-1001 KUH Perdata

Wasiat dalam KHI dan KUH Perdata pada intinya sama-sama mempunyai tujuan yang sama yaitu untuk kemaslahatan manusia agar tidak terjadi pertengkatan di antara ahli waris, karena sudah ditentukan kadar bagiannya masing-masing dalam isi wasiat tersebut.

b. Perbedaan Wasiat Dalam KHI dan KUH Perdata.

1) Orang yang Berwasiat

Dalam Inpres Nomor 1 Tahun 1991 Tentang Kompilasi Hukum Islam di Indonesia (KHI), orang yang berwasiat disyaratkan telah berumur sekurang-kurangnya 21 (dua puluh satu) tahun, berakal sehat dan dibuat tanpa ada paksaan, dapat mewasiatkan sebagian harta bendanya kepada orang lain atau pada suatu lembaga. Sedangkan dalam KUH Perdata Pasal 897 KUH dikatakan bahwa anak-anak di bawah umur yang belum mencapai umur 18 (delapan belas) tahun penuh, tidak diperkenankan membuat surat wasiat. $^{9}$

2) Pihak yang Menerima Wasiat

Pasal 171 huruf $\mathrm{f}$ KHI menjelaskan bahwa pihak yang menerima wasiat adalah orang lain atau lembaga yang akan berlaku setelah pewaris meninggal dunia. KUH Perdata menyatakan bahwa yang berhak mendapatkan wasiat adalah orang luar (yang dianggap patut menerima wasiat) dan ahli waris. ${ }^{10}$

3) Bentuk Wasiat

Dalam KHI disebutkan bahwa wasiat dapat dibuat secara lisan dihadapan dua orang saksi atau tertulis yang dilakukan dihadapan dua orang saksi atau dihadapan Notaris (Pasal 195 KHI). Dalam KHI tidak ada kewajiban dalam membuat wasiat dalam bentuk tertulis dan tidak diharuskan menggunakan campur tangan Notaris tergantung pilihan si pembuat wasiat. Sedangkan dalam KUH Perdata kaitannya

7 Maman Suparman, 2015, Hukum Waris Perdata, Sinar Grafika, Jakarta, h. 130-132.

${ }^{8}$ Maman Suparman, Op Cit, h. 133.

${ }^{9}$ Kitab Undang-Undang Hukum Perdata (Burgerlijk Wetboek), Op Cit, Hal : 240.

${ }^{10} \mathrm{http}: / /$ anugrahjayautama.blogspot.co.id/2012/0 6/hukum-waris-menurut-bw.html, Diakses Tanggal 09 Februari 2017. 
dengan bentuk wasiat, Pasal 931 KUH Perdata menyatakan surat wasiat hanya boleh dibuat, dengan akta olografis atau ditulis tangan sendiri, dengan akta umum atau dengan akta rahasia atau akta tertutup. Secara formil, dari beberapa ketentuan KUH Perdata yang disebutkan di atas, surat wasiat harus dibuat tertulis di hadapan Notaris atau dititipkan/disimpan oleh Notaris.

\section{4) Batasan Pemberian Wasiat.}

Pasal 195 ayat (2) KHI, wasiat hanya diperbolehkan sebanyak-banyaknya (maksimum) 1/3 (sepertiga) dari seluruh harta warisan. Sedangkan Menurut KUH Perdata, pada dasarnya setiap orang mempunyai kebebasan untuk mengatur mengenai apa yang akan terjadi dengan harta kekayaannya setelah meninggal dunia. Untuk melindungi ahli waris dalam keadaan berkecukupan adalah lebih baik dari pada meninggalkan mereka dalam keadaan miskin. Baikya setiap orang yang akan mewasiatkan sebagian hartanya, sebaiknya mendahulukan kepentingan ahli waris. Maka KUH Perdata mengatur batasan jumlah harta wasiat maksimal $1 / 2$ (setengah) harta jika pewasiat mempunyai seorang anak yang sah, $1 / 3$ (sepertiga) apabila memiliki dua orang anak yang sah, dan $1 / 4$ (seperempat) jika memiliki tiga orang anak yang sah termasuk dalam pengertian ini adalah anak turun mereka sebagai pengganti anak dalam garis turun masingmasing (Pasal 914 KUH Perdata) dan maksimal $1 / 2$ (setengah) jika pewasiat hanya meninggalkan ahli waris garis lurus ke atas, demikian juga terhadap anak luar kawin yang diakui telah sah (Pasal 915-916 KUH Perdata), kecuali tidak ada keluarga garis ke atas, pewasiatan tidak dibatasi (Pasal 917 KUH Perdata). ${ }^{11}$

\section{Akibat Hukum Wasiat Tanpa Adanya Akta} Notaris

Akta otentik dibuat tujuannya adalah untuk pembuktian dikemudian hari apabila terjadi sengketa. ${ }^{12}$ Secara hukum, terdapat dua fungsi akta otentik yaitu untuk menyatakan adanya suatu perbuatan hukum dan untuk pembuktian. Menurut Ika Hanyani, ${ }^{13}$ Kekuatan Pembuktian Akta Otentik di atur dalam dalam Pasal 165 HIR, Pasal 1870 dan Pasal 1871 KUH Perdata, maka dapat dikemukakan bahwa kekuatan pembuktian akta Notaris sebagai alat bukti yang sempurna, maka akta otentik memiliki

11

http://godegserelek14.blogspot.co.id/2016/04/assalamu alaikum-wr.html, Diakses Tanggal 09 Februari 2017.

${ }^{12}$ Sudikno Mertokusumo, 2002, Mengenal

Hukum, Liberty, Yogyakarta, h. 145

${ }^{13}$ Ibid, h. 27-28. semua kekuatan pembuktian baik lahir, formal, maupun material. Karena secara hukum, surat wasiat tanpa akta Notaris atau wasiat dibawah tangan ini tidak memberikan jaminan kepastian hukum karena dapat dibatalkan secara sepihak.

\section{KESIMPULAN}

1. Wasiat tanpa akta Notaris dalam pandangan KHI tidak ada kewajiban mengikut sertakan Notaris dalam pembuatan wasiat sedangkan KUH Perdata diwajibkan mengikut sertakan Notaris.

2. Persamaan wasiat tanpa akta Notaris dalam KHI dengan KUH Perdata adalah mempunyai dasar hukum tertulis, merupakan pernyataan terakhir dari pewasiat setelah sebelum meninggal dunia dan pelaksanaannya setelah si pemberi wasiat meninggal dunia, dapat dicabut dan dapat gugur atau dibatalkan, mempunyai tujuan untuk kemaslahatan manusia agar tidak terjadi pertengkatan di antara ahli waris. Perbedaan wasiat tanpa akta Notaris dalam KHI minimal umur 21 tahun sedangkan KUH Perdata minimal umur 18 tahun, dilihat dari yang menerima wasiat dalam KHI yaitu orang lain atau lembaga sedangkan KUH Perdata orang luar dan ahli waris, dilihat dari bentuknya dalam KHI yaitu lisan atau tertulis atau dihadapan Notaris sedangkan KUH Perdata tertulis di hadapan Notaris atau dititipkan/disimpan oleh Notaris, dilihat dari batasan pemberian wasiat dalam KHI yaitu maksimal 1/3 dari seluruh harta warisan sedangkan KUH Perdata maksimal 1/2 harta jika pewasiat mempunyai seorang anak, 1/3 jika memiliki dua orang anak, dan 1/4 jika memiliki tiga orang anak, kesemuanya itu merupakan anak yang sah termasuk dalam pengertian anak turun sebagai pengganti anak dalam garis turun masing-masing dan maksimal $1 / 2$ apabila pewasiat hanya meninggalkan ahli waris garis lurus ke atas, anak luar kawin yang telah diakui secara sah.

3. Akibat hukum wasiat tanpa adanya akta Notaris, menjadikan wasiat tersebut rawan akan gugatan dari pihak-pihak yang berkepentingan karena pembuktiannya kurang kuat dan tidak ada kepastian hukum.

\section{DAFTAR PUSTAKA}

Habib Adjie, 2015, Penafsiran Tematik Hukum Notaris Indonesia Berdasarkan UndangUndang Nomor 2 Tahun 2014 Tentang Perubahan Atas Undang-Undang Nomor 30 Tahun 2004 Tentang Jabatan Notaris, Refika Aditama, Bandung. 
Maman Suparman, 2015, Hukum Waris Perdata, Sinar Grafika, Jakarta.

Sudikno Mertokusumo, 2002, Mengenal Hukum, Liberty, Yogyakarta.

Sutantio, Retnowulan dan Iskandar Oeripkartawinata, 1979, Hukum Acara Perdata Dalam Teori dan Praktek, Mandar Maju, Bandung.

Yahya Harahap,1993, Kedudukan, Kewenangan dan Acara Peradilan Agama, Pustaka Kartini, Jakarta.

\footnotetext{
2010, Kitab Undang-Undang Hukum Perdata (Burgerlijk Wetboek), Citra umbara, Bandung.
}

2015, Undang-Undang R.I Nomor 1 Tahun 1974 Tentang Perkawinan \& Kompilasi Hukum Islam. Citra Umbaran, Bandung.

http://kbbi.web.id/wasiat. Diakses Tanggal 28 November 2016

http://anugrahjayautama.blogspot.co.id/2012/06/hukum -waris-menurut-bw.html, Diakses Tanggal 09 Februari 2017.

http://godegserelek14.blogspot.co.id/2016/04/assalamu alaikum-wr.html, Diakses Tanggal 09 Februari2017. 